\title{
On-pump coronary revascularization should be our preferred surgical revascularization strategy
}

\author{
Joseph F. Sabik III, MD
}

See related articles on pages 1812-9 and 1820-9 in the November 2014 issue.

Two articles in the Journal question the effectiveness of off-pump surgical revascularization. In a meta-analysis by Takagi and colleagues, patients undergoing off-pump surgery were found to have fewer grafts, more incomplete revascularization, and increased long-term mortality relative to those undergoing on-pump revascularization, and in a randomized, controlled study by Houlind and colleagues, off-pump surgery resulted in lower graft patency. Although these findings are not new, they add more evidence that off-pump revascularization is not as effective a surgical revascularization technique as on-pump revascularization and further evidence that on-pump surgery should be our preferred coronary revascularization strategy.

In the meta-analysis by Takagi and colleagues, there was a $7 \%$ increase (hazard ratio, $1.07 ; 95 \%$ confidence interval, $1.03-1.11 ; P=.0003)$ in all-cause long-term $(\geq 5$ years $)$ mortality for patients undergoing off-pump surgery compared with those undergoing on-pump surgery. Inclusion criteria for the meta-analysis were randomized, controlled trials and adjusted observational studies with at least 5 years of follow-up. From a total of 478 screened articles, 5 randomized, controlled trials and 17 adjusted observational studies were relevant and met the eligibility criteria; 104,306 patients were included in these 22 studies. A subanalysis of the 5 randomized, controlled trials (1486 patients) demonstrated a statistically nonsignificant $14 \%$ (hazard ratio, 1.14; 95\% confidence interval, 0.84-1.56; $P=.39$ ) increase in long-term mortality risk in the off-pump group; however, a subanalysis of the 17 adjusted observational studies $(102,820$ patients $)$ identified a statistically significant $7 \%$ (hazard ratio, $1.07 ; 95 \%$ confidence interval, $1.03-1.11 ; P=.0004)$ increase in long-term mortality risk in the off-pump group. Additional

From the Heart and Vascular Institute, Department of Thoracic and Cardiovascular Surgery, Cleveland Clinic Foundation, Cleveland, Ohio.

Disclosures: Author has nothing to disclose with regard to commercial support.

Received for publication Oct 13, 2014; accepted for publication Oct 14, 2014.

Address for reprints: Joseph F. Sabik III, MD, Department of Thoracic and Cardiovascular Surgery, Cleveland Clinic, Desk J4-1, 9500 Euclid Ave, Cleveland, OH 44195 (E-mail: Sabikj@ccf.org).

J Thorac Cardiovasc Surg 2014;148:2472-4

$0022-5223 / \$ 36.00$

Copyright $($ c 2014 by The American Association for Thoracic Surgery

http://dx.doi.org/10.1016/j.jtcvs.2014.10.068 worrisome observations included fewer bypass grafts and more incomplete revascularization in the off-pump group.

The randomized, controlled study by Houlind and colleagues, from the Danish On-Pump Versus Off-Pump Randomized Study (DOORS), reported inferior graft patency in patients undergoing off-pump surgery. This multicenter trial included 900 patients older than 70 years undergoing either on- or off-pump coronary artery bypass grafting. A weakness of the trial was that only 481 patients (56\% of survivors) underwent angiography at 6 months. Among these, $86 \%$ of the on-pump group had open grafts, compared with $79 \%$ of the off-pump group $(P=.01), 5 \%$ versus $9 \%$ had stenotic grafts, and $9 \%$ versus $12 \%$ had occluded grafts, respectively. Interesting secondary observations were (1) similar left internal thoracic artery patency $(95 \%)$; (2) higher frequency of stenotic or occluded vein, radial artery, and right internal thoracic artery grafts in the off-pump group; and (3) better graft patency to the anterior territory, lower in the circumflex and right territories, with a larger difference between groups favoring on-pump surgery.

Off-pump coronary surgery was popularized in the late 1990s. Its proponents had the best of intentions: to decrease the morbidity and mortality of coronary artery bypass grafting. Early observational studies comparing on- and off-pump surgery supported these intentions, demonstrating lower in-hospital morbidity and mortality with off-pump revascularization. ${ }^{1-6}$ Later well-adjusted observational studies and randomized, controlled studies disputed these early findings, however, demonstrating similar in-hospital mortality and major morbidity in patients undergoing onand off-pump surgery, with the worrisome findings of fewer bypass grafts, more incomplete revascularization, and lower graft patency in those undergoing off-pump surgery. ${ }^{7-18}$ There was less "reversible" morbidity with off-pump surgery, such as atrial fibrillation, respiratory compromise, and bleeding. ${ }^{7,18}$ A disappointing finding for proponents of off-pump revascularization was that it was associated with similar postoperative neurocognitive dysfunction to that seen in patients undergoing on-pump surgery. ${ }^{18}$

Recently, 3 well-conducted, large multicenter randomized, controlled trials have compared outcomes of onand off-pump revascularization and have confirmed these findings: ROOBY (Randomized On/Off Bypass); CORONARY (CABG Off or On Pump Revascularization Study); and GOPCABE (German Off-Pump Coronary Artery Bypass Grafting in Elderly Patients). ${ }^{15-17}$ The ROOBY trial enrolled 2203 patients undergoing coronary 
artery bypass surgery from 18 Veterans Administration medical centers in the United States. ${ }^{15}$ The CORONARY trial enrolled 4752 high-risk patients undergoing coronary artery bypass surgery at 79 centers in 19 countries. ${ }^{16}$ High-risk patients were defined by age and comorbidities, such as carotid artery stenosis, renal insufficiency, diabetes mellitus, and decreased left ventricular ejection fraction. The GOPCABE trial enrolled 2539 elderly ( $>75$ years) patients from 12 German medical institutions. ${ }^{19}$ To determine whether the lack of benefit of off-pump surgery demonstrated in multiple previous studies comparing onand off-pump surgery was due to enrolling patients who were at too low risk or surgeons who were inexperienced with off-pump techniques, both the CORONARY and GOPCABE trials included high-risk or elderly patients and were both experienced-based randomized, controlled trials.

All 3 trials reported similar 30-day figures for mortality, stroke, and acute renal failure requiring dialysis in the onand off-pump surgery groups. ${ }^{15-17}$ The CORONARY and GOPCABE studies also reported similar 30-day risks of myocardial infarction. A concerning, but not unexpected, finding in all 3 studies was fewer bypass grafts, suggesting more incomplete revascularization in patients undergoing off-pump surgery. The ROOBY study evaluated graft patency and found that both saphenous vein graft and internal thoracic artery graft patencies were lower in the off-pump surgery group. The CORONARY and GOPCABE studies reported higher prevalence of 30-day coronary reintervention in their off-pump surgery groups, suggesting less effective revascularization because of either lower graft patency or incomplete revascularization. The ROOBY study also reported higher 1-year cardiac mortality in the off-pump surgery group. Despite greater surgeon experience, patients at higher risk, and advances in off-pump surgical techniques, no early decrease in mortality, stroke, myocardial infarction, or renal failure requiring dialysis was demonstrated with off-pump revascularization, and the worrisome findings of fewer grafts, more incomplete revascularization, lower graft patency, and higher 1-year mortality in patients undergoing off-pump surgery were once again reported.

The reports by Takagi and colleagues and Houlind and colleagues add to many other studies demonstrating that off-pump coronary surgery results in fewer bypass grafts, less complete revascularization, lower graft patency, and higher long-term mortality than on-pump surgery. The effectiveness of coronary artery bypass grafting is related directly to graft patency and completeness of revascularization, and it should not be surprising that higher late mortality is associated with off-pump surgery. ${ }^{20-23}$ These observations strongly suggest that on-pump surgery should be our preferred revascularization technique and that off-pump surgery should be reserved for patients for whom the risk of cardiopulmonary bypass is greater than the risk of a less effective revascularization, such as those with extensive aortic atherosclerosis. It is time for us to admit that despite our best efforts, we routinely cannot do as good a surgical revascularization off pump as we can do on pump.

\section{References}

1. Calafiore AM, Teodori G, Di Giammarco G, Vitolla G, Maddestra N, Paloscia L, et al. Multiple arterial conduits without cardiopulmonary bypass: early angiographic results. Ann Thorac Surg. 1999;67:450-6.

2. Koutlas TC, Elbeery JR, Williams JM, Moran JF, Francalancia NA, Chitwood WR Jr. Myocardial revascularization in the elderly using beating hear coronary artery bypass surgery. Ann Thorac Surg. 2000;69:1042-7.

3. Iacò AL, Contini M, Teodori G, Di Mauro M, Di Giammarco G, Vitolla G, et al Off or on bypass: what is the safety threshold? Ann Thorac Surg. 1999;68: 1486-9.

4. Buffolo E, de Andrade CS, Branco JN, Teles CA, Aguiar LF, Gomes WJ Coronary artery bypass grafting without cardiopulmonary bypass. Ann Thorac Surg. 1996;61:63-6.

5. Puskas JD, Wright CE, Ronson RS, Brown WM III, Gott JP, Guyton RA Off-pump multivessel coronary bypass via sternotomy is safe and effective. Ann Thorac Surg. 1998;66:1068-72.

6. Yokoyama T, Baumgartner FJ, Gheissari A, Capouya ER, Panagiotides GP, Declusin RJ. Off-pump versus on-pump coronary bypass in high-risk subgroups Ann Thorac Surg. 2000;70:1546-50.

7. Sabik JF, Gillinov AM, Blackstone EH, Vacha C, Houghtaling PL, Navia J, et al Does off-pump coronary surgery reduce morbidity and mortality? J Thorac Cardiovasc Surg. 2002;124:698-707.

8. Contini M, Iacò A, Iovino T, Teodori G, Di Giammarco G, Mazzei V, et al. Current results in off pump surgery. Eur J Cardiothorac Surg. 1999;16(Suppl 1):S69-72.

9. Bull DA, Neumayer LA, Stringham JC, Meldrum P, Affleck DG, Karwande SV. Coronary artery bypass grafting with cardiopulmonary bypass versus off-pump cardiopulmonary bypass grafting: does eliminating the pump reduce morbidity and cost? Ann Thorac Surg. 2001;71:170-3; discussion 173-5.

10. Kshettry VR, Flavin TF, Emery RW, Nicoloff DM, Arom KV, Petersen RJ. Does multivessel, off-pump coronary artery bypass reduce postoperative morbidity? Ann Thorac Surg. 2000;69:1725-30; discussion 1730-1.

11. Czerny M, Baumer H, Kilo J, Zuckermann A, Grubhofer G, Chevtchik O, et al Complete revascularization in coronary artery bypass grafting with and without cardiopulmonary bypass. Ann Thorac Surg. 2001;71:165-9.

12. Arom KV, Flavin TF, Emery RW, Kshettry VR, Janey PA, Petersen RJ. Safety and efficacy of off-pump coronary artery bypass grafting. Ann Thorac Surg. 2000;69: 704-10.

13. Lim E, Drain A, Davies W, Edmonds L, Rosengard BR. A systematic review of randomized trials comparing revascularization rate and graft patency of off-pump and conventional coronary surgery. J Thorac Cardiovasc Surg. 2006;132: 1409-13.

14. Racz MJ, Hannan EL, Isom OW, Subramanian VA, Jones RH, Gold JP, et al. A comparison of short- and long-term outcomes after off-pump and on-pump coronary artery bypass graft surgery with sternotomy. J Am Coll Cardiol. 2004; 43:557-64

15. Shroyer AL, Grover FL, Hattler B, Collins JF, McDonald GO, Kozora E, et al; Veterans Affairs Randomized On/Off Bypass Study Group. On-pump versus off-pump coronary-artery bypass surgery. N Engl J Med. 2009;361: 1827-37.

16. Lamy A, Devereaux PJ, Prabhakaran D, Taggart DP, Hu S, Paolasso E, et al; Coronary Investigators. Off-pump or on-pump coronary-artery bypass grafting at 30 days. $N$ Engl J Med. 2012;366:1489-97.

17. Diegeler A, Börgermann J, Kappert U, Breuer M, Böning A, Ursulescu A, et al GOPCABE Study Group. Off-pump versus on-pump coronary-artery bypass grafting in elderly patients. $N$ Engl J Med. 2013;368:1189-98.

18. Cheng DC, Bainbridge D, Martin JE, Novick RJ, Evidence-Based Perioperative Clinical Outcomes Research Group. Does off-pump coronary artery bypass reduce mortality, morbidity, and resource utilization when compared with conventional coronary artery bypass? A meta-analysis of randomized trials. Anesthesiology. 2005;102:188-203. 
19. Diegeler A, Reents W, Zacher M. Off-pump or on-pump coronary-artery bypass grafting. N Engl J Med. 2013;369:196-7.

20. Scott R, Blackstone EH, McCarthy PM, Lytle BW, Loop FD, White JA, et al. Isolated bypass grafting of the left internal thoracic artery to the left anterior descending coronary artery: late consequences of incomplete revascularization. J Thorac Cardiovasc Surg. 2000;120:173-84.

21. Jones EL, Weintraub WS. The importance of completeness of revascularization during long-term follow-up after coronary artery operations. J Thorac Cardiovasc Surg. 1996;112:227-37.
22. Bell MR, Gersh BJ, Schaff HV, Holmes DR Jr, Fisher LD, Alderman EL, et al. Effect of completeness of revascularization on long-term outcome of patients with three-vessel disease undergoing coronary artery bypass surgery. A report from the Coronary Artery Surgery Study (CASS) Registry. Circulation. 1992; 86:446-57.

23. Liao L, Kong DF, Shaw LK, Sketch MH Jr, Milano CA, Lee KL, et al, A new anatomic score for prognosis after cardiac catheterization in patients with previous bypass surgery. J Am Coll Cardiol. 2005;46: 1684-92. 